\title{
14C BMS-275183
}

National Cancer Institute

\section{Source}

National Cancer Institute. 14C BMS-275183. NCI Thesaurus. Code C62553.

An orally bioavailable taxane compound, a C-4 methyl carbonate analogue of paclitaxel, labeled with radioactive carbon 14 , with potential antineoplastic and radioimaging activities. BMS-275183 binds to tubulin and as a result inhibits microtubule disassembly or assembly. This leads to cell cycle arrest at the G2/M phase, thereby resulting in an inhibition of cell division and ultimately cell death. BMS-275183 may be useful for treating multi-drug resistant tumors as it does not appear to be a substrate for P-glycoprotein. 